\title{
Correlation Between Vitamin D Level and Platelet Indices in Children Aged 0-18 Years
}

\author{
0-18 Yaş Çocuklarda Vitamin D Düzeyi ile Trombosit indeksleri Arasındaki ilişki \\ • Cihan Coşkun, • Kamil Şahin* \\ University of Health Sciences, Haseki Traning and Research Hospital, Clinic of Biochemistry, Istanbul, Turkey \\ *University of Health Sciences, Haseki Traning and Research Hospital, Clinic of Pediatri, Istanbul, Turkey
}

\section{Abstract}

Aim: In this study, we aimed to investigate whether any correlation exists between 25-hidroxyvitamin D [25(OH)D)] level and platelet indices in childhood.

Methods: We planned a retrospective study. Firstly, we scanned 25(OH) $\mathrm{D}$ and hemogram tests in children who presented to our pediatric clinic with any simple complaint from January 2014 to December 2016. We finally included 346 children (168 female and 178 male) aged 0-18 years in order to evaluate the correlation between $25(\mathrm{OH}) \mathrm{D}$ level and platelet indices.

Results: No significant difference was observed in average age and gender between the study groups $(p=0.856$ and $p=0.907$, respectively). We did not determine any significant difference among seasons in terms of 25(OH)D level $(p=0.512)$. Finally, we also did not find any correlation between $25(\mathrm{OH}) \mathrm{D}$ and platelet indices in all groups ( $p>0.05)$.

Conclusion: There was no relationship between 25(OH)D level and platelet indices in healthy children.

Keywords: 25-hidroxyvitamin D, deficiency, platelet count, mean platelet volume, child
Öz

Amaç: Bu çalışmada, 25 hidroksivitamin D düzeyi [25(OH)D] ile trombosit indeksleri arasında ilişki olup olmadığını araştırmayı amaçladık.

Yöntemler: Retrospektif bir çalışma planladık. Öncelikle, 2014 Ocak ayı ile 2016 Aralık ayları arasında basit şikayetler ile çocuk kliniğine başvurmuş çocukların 25(OH)D ve hemogram testlerini taradık. Sonuç olarak, yaşları 0-18 arasında olan 346 çocuğu (168kı, 178 erkek), 25(OH)D düzeyleri ve trombosit indeksleri arasındaki ilişkiyi değerlendirmek için çalışmaya dahil ettik.

Bulgular: Çalışma gruplarının yaş ortalaması ve cinsiyetleri arasında anlamlı fark gözlemlenmedi ( $p=0,856$ ve $p=0,907)$. 25(OH)D düzeyi bakımından mevsimler arasında herhangi önemli bir fark tespit etmedik $(p=0,512)$. Son olarak, tüm gruplardaki 25(OH)D düzeyi ile trombosit indeksleri arasında da herhangi bir ilişki bulamadık $(p>0,05)$.

Sonuç: Sağlıklı çocuklarda 25(OH)D düzeyi trombosit indeksleri ile ilişkili değildi. Bununla birlikte, bulgularımızı doğrulayacak daha ileri çalışmalara ihtiyaç olduğu düşüncesindeyiz.

Anahtar Sözcükler: 25 hidroksivitamin D, eksiklik, trombosit sayısı, ortalama trombosit hacmi, çocuk

including PLT count, plateletcrit (PCT), PLT distribution width (PDW) and mean PLT volume (MPV) are widely used in the field of medicine (3). It has been recently revealed that these indices are associated with various diseases and the prognosis of various diseases as well as hematological system disorders $(4,5)$. However, whether PLT indices are
Address for Correspondence/Yazışma Adresi: Cihan Coşkun

University of Health Sciences, Haseki Traning and Research Hospital, Clinic of Biochemistry, istanbul, Turkey

Phone: +90 5052620824 E-mail: kuzeycihan2012@gmail.com ORCID ID: orcid.org/0000-0001-8288-8741

Received/Geliş Tarihi: 24 July 2017 Accepted/Kabul Tarihi: 11 December 2017
${ }^{\circ}$ Copyright 2018 by The Medical Bulletin of University of Health Sciences Haseki Training and

Research Hospital aseki published by Galenos Yayınevi.

${ }^{\circledR}$ Telif Hakkı 2018 Sağlık Bilimleri Üniversitesi Haseki Eğitim ve Araştırma Hastanesi Haseki Tıp Bülteni, Galenos Yayınevi tarafından basılmıştır. 
related to the severity of diseases and patient prognosis or not is still under investigation (6). Under physiological conditions, the amount of PLTs in blood can be maintained in a constant state by regeneration and elimination. Thus, either PLTs or their morphology remain almost stable. Impairment of these conditions by any pathophysiological conditions, which can inhibit PLT production, may increase their activation or cause their death, leading to changes in both PLT count and morphology and, thus, resulting in alterations in PLT indices (7). In a meta-analysis, it was reported that increased MPV was related to mortality after acute myocardial infarction (MI) and restenosis following coronary angioplasty (8). The relationship of increased MPV with severity of sepsis (9), diabetes mellitus (DM) (10), stroke (11), hypertension (12) and venous thromboembolism (13) as well as MI has been reported (8). In their study, Abdel-Razik et al. (14), MPV and PDW were significantly increased in patients with ascitic fluid infection and it was concluded that MPV measurement could be considered a diagnostic test in predicting ascitic fluid infection.

Vitamin D is essential for calcium metabolism and bone structure. Its deficiency is associated with rickets in children (15). It has been reported that vitamin D deficiency was associated with several pathological conditions, such as cardiovascular diseases, cancer and DM, although all the mechanisms have not been fully understood $(10,14)$. In a few studies carried out on healthy adults, it was stated that vitamin $D$ deficiency may lead to immunological disorders, inflammation and increases in the level of various proinflammatory cytokines, thus, that vitamin $D$ deficiency may cause increased MPV through increasing cytokines and adhesion molecules $(16,17)$.

We aimed to evaluate whether there was any correlation between some PLT indices and 25 hidroksivitamin D $[25(\mathrm{OH}) \mathrm{D}]$ in children aged 0-18 years since there has not been any study investigating this issue in childhood.

\section{Methods}

\section{Study Design}

We carried out a retrospective study including 346 children (168 female and 178 male) who were admitted to the pediatric clinic with any simple complaint and underwent laboratory tests, including 25(OH)D and PLT indices from January 2014 to December 2016. Blood samples were taken at different seasons. Ethics committee approval was received for this study from the Local Ethics Committee of Haseki Training and Research Hospital (approval date: 21/06/2017, approval number: 510).

We divided the patients into three groups: group 1 included children with a 25(OH)D level of $<20 \mathrm{ng} / \mathrm{mL}$; group 2 included those with a 25(OH)D level of 20-32 ng/
$\mathrm{mL}$; and group 3 consisted of individuals with a $25(\mathrm{OH})$ D level of $>32 \mathrm{ng} / \mathrm{mL}$. A 25(OH)D level of $<20 \mathrm{ng} / \mathrm{mL}$ was considered deficiency, a level of $20-32 \mathrm{ng} / \mathrm{mL}$ was considered insufficiency, and a level of $>32 \mathrm{ng} / \mathrm{mL}$ was considered adequacy (18).

Serum levels of 25(OH)D were measured by a direct competitive chemiluminescence immunoassay method on the Liaison Analyzer (DiaSorin S.p.A., Italy). PLT count was analyzed by hydrodynamic focusing (DC detection). MPV was calculated by the following formula: MPV $(f L)=[(P C T$ $(\%) /$ PLT count $\left.\left(\times 10^{9} / \mathrm{L}\right)\right]$. PCT was the ratio of the PLT volume to the whole blood volume. PDW was determined by using a histogram of PLT particle size distribution. PLT indices were analyzed using Sysmex XE-2100 hematology analyzer (TOA Medical Electronics, Kobe, Japan). Other laboratory tests were conducted by spectrophotometric method using AU2700 biochemical auto-analyzer (Beckman Coulter, Inc. USA).

\section{Statistical Analysis}

Statistical analysis was carried out using the Statistical Package for Social Sciences 21 (SPSS) package program (IBM, New York, USA). Data were summarized using mean $(X)$, and standard deviation (SD) for quantative variables. Normality of the quantitative data was evaluated using the Kolmogorov-Smirnov test. Homogeneity of variances was evaluated via Levene's test for each group. A chisquare test was used for evaluating categorical variables. One-Way ANOVA test was performed to examine the differences between the groups. Student's t-test was used to compare the results obtained from both sexes. Pearson correlation coefficient was then applied to evaluate the relationship of 25(OH)D with PLT indices and other biochemical variables. The probability value $(p)$ was set at $<0.05$. The results were reported as $(X) \pm S D$. The power of this study was carried out through using the function of SPSS named as calculating power and probability of type 2 error (beta) value.

\section{Results}

There was no statistically significant difference in average age and sex between the study groups. The power of this study, which involves three groups, was calculated to be 1 . The type 1 error was set at $80 \%$, and the type 2 error ( $p$ ) was set at 0.05 . There was no significant difference among the groups in terms of mean PLT indices and various biochemical analytes ( $p>0.05$, for all) except for the level of 25(OH)D $(p<0.001)$. Demographic characteristics and laboratory test results in each group together with the $p$ values are given in Table 1. $25(\mathrm{OH})$ $\mathrm{D}$ and PLT indices were examined after each group was categorized according to sex. When these data were evaluated within the groups, there was no significant 
difference in all parameters between genders ( $p>0.05$ for all) (Table 2). In addition, no difference was determined among seasons $(p=0.512)$ in terms of $25(\mathrm{OH}) \mathrm{D}$ levels $(p=0.512)$ (Table 3$)$.

There was no correlation between 25(OH)D levels and MPV $(r=0.073, p=0.257)$ and PDW $(r=0.001, p=0.986)$ in all groups. Similarly, no correlation was observed between 25(OH)D and PLT count $(r=0.062, p=0.329)$. PCT had also no correlation with $25(\mathrm{OH}) \mathrm{D}(\mathrm{r}=0.086, \mathrm{p}=0.177)$ and other PLT indices. Moreover, 25(OH)D had no correlation with calcium, phosphorus, and alkaline phosphatase, however, there was a very weak negative correlation between parathyroid hormone and 25(OH)D in group $1(r=-0.238$, $p=0.108$ ), as a result of comparison within subgroups.

Finally, the age of children did not have an effect on 25(OH)D, PDW and PCT values, whereas MPV had a weak positive correlation with age $(r=0.338, p<0.001)$. There was a weak inverse correlation between PLT count and age $(r=-0.263, p<0.001)$.

\section{Discussion}

In the literature, there are few studies including adults, however, to our knowledge, this is the first study conducted in children. In this study, we did not find any correlation between 25(OH)D and PLT indices in all groups. This result means that vitamin $D$ deficiency was not associated with increased MPV. On the contrary, a study conducted in adult subjects with vitamin $D$ deficiency revealed that there was a negative correlation between vitamin $D$ and MPV (16). A similar result was also found by another study involving patients with primary ovarian insufficiency (POI); it was reported that vitamin D was negatively correlated

\begin{tabular}{|c|c|c|c|c|}
\hline & Group $1(n=170)$ & Group $2(n=95)$ & Group $3(n=81)$ & $p$ value \\
\hline Age (years) & $5.7 \pm 5.8$ & $6.7 \pm 5.9$ & $6.6 \pm 5.9$ & 0.856 \\
\hline Gender (female/male) & $81 / 89$ & $46 / 49$ & $41 / 40$ & 0.907 \\
\hline Platelets $\left(\times 10^{9} / \mathrm{L}\right)$ & $322 \pm 85$ & $306 \pm 76$ & $325 \pm 76$ & 0.298 \\
\hline MPV (fL) & $8.9 \pm 1.1$ & $8.9 \pm 1.1$ & $9.0 \pm 1.1$ & 0.196 \\
\hline PDW (fL) & $14.3 \pm 2.2$ & $14.2 \pm 2.3$ & $14.8 \pm 2.0$ & 0.510 \\
\hline РСТ (\%) & $0.29 \pm 0.07$ & $0.27 \pm 0.07$ & $0.29 \pm 0.06$ & 0.152 \\
\hline Calcium (mg/dL) & $10.0 \pm 0.4$ & $9.9 \pm 0.4$ & $9.9 \pm 0.5$ & 0.124 \\
\hline Phosphorus (mg/dL) & $5.0 \pm 0.7$ & $4.9 \pm 0.7$ & $5.0 \pm 0.8$ & 0.767 \\
\hline $\operatorname{ALP}(I U / L)$ & $245 \pm 132$ & $249 \pm 100$ & $233 \pm 93$ & 0.699 \\
\hline PTH $(\mathrm{pg} / \mathrm{mL})$ & $36 \pm 18$ & $38 \pm 16$ & $40 \pm 21$ & 0.583 \\
\hline Vitamin D (ng/mL) & $11.9 \pm 4.2$ & $25.0 \pm 3.4$ & $42.8 \pm 10.0$ & $<0.001$ \\
\hline
\end{tabular}

\begin{tabular}{|c|c|c|c|c|c|c|}
\hline \multirow{2}{*}{$\begin{array}{l}\text { Variables } \\
\text { Gender }(n)\end{array}$} & \multicolumn{2}{|c|}{ Group 1} & \multicolumn{2}{|c|}{ Group 2} & \multicolumn{2}{|c|}{ Group 3} \\
\hline & Female (81) & Male (89) & Female (46) & Male (49) & Female (41) & Male (40) \\
\hline $\begin{array}{l}\text { Vitamin D } \\
(\mathrm{ng} / \mathrm{mL})\end{array}$ & $11.5 \pm 4.1$ & $12.4 \pm 4.2$ & $25.4 \pm 3.4$ & $24.7 \pm 3.4$ & $44.3 \pm 8.9$ & $41.3 \pm 10.9$ \\
\hline $\begin{array}{l}\text { Platelets } \\
\left(\times 10^{9} / \mathrm{L}\right)\end{array}$ & $326 \pm 75$ & $304 \pm 85$ & $300 \pm 71$ & $315 \pm 93$ & $333 \pm 68$ & $306 \pm 78$ \\
\hline MPV (fL) & $9.0 \pm 1.2$ & $9.0 \pm 0.9$ & $9.2 \pm 1.0$ & $9.0 \pm 1.4$ & $9.1 \pm 1.0$ & $9.2 \pm 1.2$ \\
\hline PDW (fL) & $14.3 \pm 2.2$ & $14.3 \pm 2.3$ & $13.7 \pm 2.5$ & $14.6 \pm 1.8$ & $14.7 \pm 2.1$ & $14.2 \pm 2.0$ \\
\hline РСТ (\%) & $0.29 \pm 0.07$ & $0.28 \pm 0.07$ & $0.29 \pm 0.07$ & $0.28 \pm 0.09$ & $0.30 \pm 0.06$ & $0.29 \pm 0.08$ \\
\hline
\end{tabular}

\section{Table 3. The mean values of vitamin D according to seasons}

\begin{tabular}{|l|l|l|l|l|l|}
\hline Variables & Summer & Autumn & Spring & Winter & p value \\
\hline Vitamin $\mathrm{D}(\mathrm{ng} / \mathrm{mL})$ & $23.71 \pm 15.15$ & $23.0 \pm 12.5$ & $21.1 \pm 12.3$ & $22.9 \pm 14.7$ & 0.512 \\
\hline
\end{tabular}


with MPV, and patients with POI had lower vitamin D and higher MPV than controls (19). We also observed that there was no correlation between vitamin D and PDW. We also did not find any correlation between vitamin $D$ and PLT count and PCT in all groups. We did not find any study on the association of vitamin D with PLT and PCT in the literature. However, PCT, the arithmetic product of the PLT count and volume, is also a reliable marker of PLT activation as well as MPV, and a positive correlation has also been reported between PCT and PLTs in previous studies (20). This knowledge regarding PLT and PCT may explain why there was no correlation between these indices and vitamin $\mathrm{D}$.

The age of children did not have any effect on $25(\mathrm{OH})$ $D$, PDW and PCT. There was a weak negative correlation between PLT count and age and a weak positive correlation between MPV and age in all groups. Our findings were fairly consistent with the literature, except for MPV which displayed inconsistent results in previous studies (21). We also observed that there was no difference between genders in terms of 25(OH)D levels and PLT indices in all groups. However, a study reported that PLT indices, except for PDW, were higher in female patients than in males (21). In accordance with our study, other studies reported that there was no difference in vitamin $D$ levels and PDW between genders $(16,22)$. On the contrary, a study reported that females had borderline significantly higher 25(OH)D levels than in men (23). In addition, we did not observe a seasonal variation of $25(\mathrm{OH}) \mathrm{D}$ levels. The reason may be that vitamin $D$ intake and sun exposure could not be inqured exactly in all subjects since the present study had a retrospective study design. Whereas, some studies have reported the effects of vitamin $D$ intake and sun exposure on the level of vitamin $D(24,25)$.

Our study has some limitations: firstly, it has a retrospective nature. Besides, some diseases, which may be caused by PLT activation, could not be assessed in this study. Prospective studies with larger samples, which may enable more detailed inquiry of subjects, i.e. status of vitamin D intake in children as well as including subjects with some diseases being claimed to cause larger PLTs originating from PLT activation.

\section{Conclusion}

It was found that 25(OH)D levels were not related to PLT indices in healthy children. On the other hand, we assume that further studies are needed to validate our findings.

\section{Authorship Contributions}

Surgical and Medical Practices: K.Ş. Concept: C.C., K.Ş. Design: C.C. Data Collection or Processing: K.Ş. Analysis or Interpretation: C.C., K.Ş. Literature Search: C.C. Writing: C.C.
Conflict of Interest: No conflict of interest was declared by the authors.

Financial Disclosure: The authors declared that this study has received no financial support.

\section{References}

1. Beyan C, Kaptan K, Irfan A. Platelet count, mean platelet volume, platelet distribution width, and plateletcrit do not correlate with optical platelet aggregation responses in healthy volunteers. J Thromb Thrombolysis 2006;22:161-4.

2. Guclu E, Durmaz Y, Karabay O Effect of severe sepsis on platelet count and their indices. Afr Health Sci 2013;13:3338.

3. Zhang $\mathrm{Z}, \mathrm{Xu} \mathrm{X}, \mathrm{Ni} \mathrm{H}$, Deng $\mathrm{H}$. Platelet indices are novel predictors of hospital mortality in intensive care unit patients. J Crit Care 2014;29:885.e1-6.

4. Sezgi C, Taylan M, Kaya $\mathrm{H}$, et al. Alterations in platelet count and mean platelet volume as predictors of patient outcome in the respiratory intensive care unit. Clin Respir J 2015;9:4038.

5. Knaus WA, Draper EA, Wagner DP, Zimmerman JE. APACHE II: A severity of disease classification system. Crit Care Med 1985;13:818-29.

6. Zhang S, Cui YL, Diao MY, Chen DC, Lin ZF. Use of Platelet Indices for Determining Illness Severity and Predicting Prognosis in Critically III Patients. Chin Med J 2015;128:2012-8.

7. Gadó K, Domján G. Thrombocytopenia. Orv Hetil 2014;155:291-303.

8. Chu SG, Becker MD, Berger PB, et al. Mean platelet volume as a predictor of cardiovascular risk: a systematic review and meta-analysis. J Thromb Haemost 2009;8:148-56.

9. Catal F, Tayman C, Tonbul A, et al. Mean platelet volume (MPV) may simply predict the severity of sepsis in preterm infants Clin Lab 2014;60:1193-200.

10. Kodiatte TA, Manikyam UK, Rao SB, et al. Mean platelet volume in Type 2 diabetes mellitus. J Lab Physicians 2012;4:59.

11. Cho SY, Jeon YL, Choi SK, Suh JT, Lee HJ, Park TS. Mean platelet volume in Korean patients with acute ischemic stroke: a gender difference. Platelets 2013;24:75-6.

12. Bulur S, Önder HI, Aslantas Y, et al. Relation between indices of end-organ damage and mean platelet volume in hypertensive patients. Blood Coagul Fibrinolysis 2012;23:367-9.

13. Gulcan M, Varol E, Etli M, Aksoy F, Kayan M. Mean platelet volume is increased in patients with deep vein thrombosis. Clin Appl Thromb Hemost 2012;18:427-30.

14. Abdel-Razik A, Eldars W, Rizk E. Platelet indices and inflammatory markers as diagnostic predictors for ascitic fluid infection. Eur J Gastroenterol Hepatol 2014;26:1342-7.

15. Misra M, Pacaud D, Petryk A, et al. Vitamin D deficiency in children and its management: review of current knowledge and recommendations. Pediatrics 2008;122:398-417.

16. Cumhur Cure M, Cure E, Yuce S, Yazici T, Karakoyun I, Efe $\mathrm{H}$. Mean platelet volume and vitamin D level. Ann Lab Med 2014;34:98-103. 
17. Cure E, Balik MS, Cumhur Cure M, et al. Is the mean platelet volume predictive of hip fractures in the elderly? Ann Lab Med 2013;33:367-70.

18. Elevli M, Bozacı AE, Şahin K, Duru HN, Çivilibal M, Aktaş BB. Evaluation of serum 25-hidroxy vitamin $D$ and zinc levels in asthmatic patients. Turk J Biochem 2016; doi 10.1515/tjb2017-0002.

19. Kebapcilar AG, Kulaksizoglu M, Ipekci SM, et al. Relationship between mean platelet volume and low-grade systemic coagulation with vitamin $D$ deficiency in primary ovarian insufficiency. Arch Gynecol Obstet 2013;288:207-12.

20. Howarth S, Marshall LR, Barr AL, Evans S, Pontre M, Ryan N. Platelet indices during normal pregnancy and pre-eclampsia. Br J Biomed Sci 1999;56:20-2.

21. Santimone I, Di Castelnuovo A, De Curtis A, et al. White blood cell count, sex and age are major determinants of heterogeneity of platelet indices in an adult general population: results from the MOLI-SANI project. Haematologica 2011;96:1180-8.

22. Carnevale $\mathrm{V}$, Modoni S, Pileri $\mathrm{M}$, et al. Longitudinal evaluation of vitamin D status in healthy subjects from southern Italy: seasonal and gender differences. Osteoporos Int 2001;12:1026-30.

23. Hagenau T, Vest R, Gissel TN, et al. Global vitamin D levels in relation to age, gender, skin pigmentation and latitude: an ecologic meta-regression analysis. Osteoporos Int 2009;20:133-40.

24. Krall EA, Sahyoun N, Tannenbaum S, Dallal GE, DawsonHughes B. Effect of vitamin D intake on seasonal variations in parathyroid hormone secretion in postmenopausal women. N Engl J Med 1989;321:1777-83.

25. Holick MF, Chen TC. Vitamin D deficiency: a worldwide problem with health consequences. Am J Clin Nutr 2008;87:1080-6. 